\title{
CHROMATOGRAPHIC INVESTIGATION OF RUTHENIUM NITROSYL COMPLEX: NO INTERCONVERSION AND REACTIONS WITH BIOLOGICAL REDUCTANTS
}

\author{
Francisco O. N. da Silva*,a, Dayana P. S. Penha ${ }^{a}$, Ana E. V. de Alencara, Daniel de L. Pontes ${ }^{a}$, Ana C. F. de B. Pontes \\ Eduardo H. S. Sousa ${ }^{b}$ and Luiz G. F. Lopes ${ }^{b}$ \\ anstituto de Química, Universidade Federal do Rio Grande do Norte, 59078-970, Natal - RN, Brasil \\ bDepartamento de Química Orgânica e Inorgânica, Universidade Federal do Ceará, 60440-900 Fortaleza - CE, Brasil
}

Recebido em 22/09/2017; aceito em 06/12/2017; publicado na web em 18/01/2018

\begin{abstract}
One experimental strategy to prepare a nitrosyl metal complex is based on the acid-base conversion of $\mathrm{NO}_{2}^{-}$into $\mathrm{NO}^{+}$. Here, we employed UV-vis absorption and FTIR spectroscopies to investigate the reaction of $c$ is- $\left[\mathrm{Ru}\left(\mathrm{NO}_{2}\right)(\mathrm{bpy})_{2}(\mathrm{imN})\right] \mathrm{PF}_{6}$ with $\mathrm{H}_{3} \mathrm{O}^{+}$, which produced cis- $\left[\mathrm{Ru}(\mathrm{NO})(\mathrm{bpy})_{2}(\mathrm{imN})\right]\left(\mathrm{PF}_{6}\right)_{3}$ complex. Chromatographic studies were carried out and showed that immediately after nitrite complex was dissolved only one species was present with retention time $\left(\mathrm{t}_{\mathrm{R}}\right)$ of 6.81 minutes. Addition of $\mathrm{H}_{3} \mathrm{O}^{+}$to nitrite complex led to the formation of one major peak with $t_{R}$ of $3.92 \mathrm{~min}$ supporting nitrosyl complex formation. The reaction of nitrosyl complex with cysteine was also monitored by HPLC and it showed clearly the formation and followed decrease of a peak at 3.38 minute with maximum absorption at $380 \mathrm{~nm}$, consistent with an intermediate complex. Later, it was observed the appearance of a peak at 4.15 minute with absorption band at $470 \mathrm{~nm}$. In contrast to the reaction with cysteine, methionine did not show the formation of any intermediate. The use of HPLC was an important tool to support mechanistic assumptions for nitrosyl reactions.
\end{abstract}

Keywords: nitrite/nitrosyl interconversion; ruthenium; cysteine and HPLC.

\section{INTRODUCTION}

For over three decades, nitric oxide effects on biological systems have been studied revealing many important roles and medical implications..$^{1-6}$ Due to this, ruthenium nitrosyl complexes have emerged as an efficient system for the design of NO donors with potential pharmacological applications. ${ }^{7-10}$ The most common synthetic route to prepare ruthenium nitrosyl complexes is based on the conversion of coordinated $\mathrm{NO}_{2}{ }^{-}$into $\mathrm{NO}^{+} .{ }^{10}$ However, as far as we are concerned, a careful monitoring of this reaction using HPLC has never been reported in literature.

The reactivity, photochemical and stereochemical properties of ruthenium bipyridine complexes have been increasingly investigated. ${ }^{10-20}$ These studies were carried out mainly using spectroscopic and electrochemical techniques. However, these techniques can have some drawbacks, based on the fact they might not detect small amount of impurities neither better describe composition of a mixture of species. Despite these advantages, there are not many cases reported in the literature where the reactivity of metal complexes was investigated using HPLC. Nevertheless, the study of reactivity of ruthenium bipyridine complexes can be a suitable example for the use of HPLC. Identification of an intermediate along with optimization of new synthetic route were described for $\operatorname{cis}$ - $\left[\mathrm{Ru}(\mathrm{bpy})_{2}(\mathrm{~L})_{2}\right]^{2+}$ complex, ${ }^{21}$ along with a few other cases. $^{22-25}$

However, many other cases have not taken advantage of this technique to better address more complex problems and separations as well. For example, the trans- $\left[\mathrm{Ru}(\mathrm{bpy})_{2}(\mathrm{XY})_{2}\right]^{2+}$ compounds are prepared by photoisomerization of cis- $\left[\mathrm{Ru}(\mathrm{bpy})_{2}\left(\mathrm{H}_{2} \mathrm{O}\right)_{2}\right]^{2+}$ following binding of $\mathrm{X}$ and $\mathrm{Y}$ ligands. ${ }^{26}$ This photoreaction is still quite inefficient and very often difficult to obtain complexes with high purity.

Another case is related to the nitrosyl/nitrite equilibrium in a metal complex, which is dependent on the $\mathrm{pH}$ as described below

*e-mail: ordeleisilva@yahoo.com.br
(Equation 1). ${ }^{27-34}$ These species exhibit quite distinct overall charge, which can strongly alter interaction with reverse phase column.

$\left[\mathrm{Ru}(\mathrm{NO})(\mathrm{bpy})_{2} \mathrm{~L}\right]^{\mathrm{n}}+2 \mathrm{OH}^{-} \rightleftharpoons\left[\mathrm{Ru}\left(\mathrm{NO}_{2}\right)(\mathrm{bpy})_{2} \mathrm{~L}\right]^{\mathrm{n}-2}+\mathrm{H}_{2} \mathrm{O}$

Sometimes nitrosyl complexes of the type $\left[\mathrm{Ru}(\mathrm{NO})(\mathrm{bpy})_{2} \mathrm{~L}\right]^{3+}$ can be easily converted into the nitrite form even at low $\mathrm{pH} .{ }^{35}$ Thus it is necessary to work in a highly acidic medium to shift the equilibrium to the nitrosyl form.

The reactions with thiolates are more complicated than with $\mathrm{OH}^{-}$, because irreversible processes occur with subsequent adduct formation. Some reactions of nucleophiles with nitrosyl complexes have been reviewed, ${ }^{36-40}$ leading to the formation of gas $\left(\mathrm{N}_{2}\right.$ or $\left.\mathrm{N}_{2} \mathrm{O}\right)$ as result of the adduct decompositions. Intermediate adducts have showed strong absorption around $520 \mathrm{~nm}$ as noticed during a fast reactions of nitroprusside and diverse thiolates, ${ }^{41-43}$ leading to the reduction of nitric oxide and the oxidation of the thiolates. ${ }^{44-49}$

In this work we report the monitoring of the reaction involving the nitrite/nitrosyl interconversion and sulfur-based compounds with cis- $\left[\mathrm{Ru}(\mathrm{NO})(\mathrm{bpy})_{2}(\mathrm{imN})\right]^{3+}$. These studies can validate the suitable use of HPLC for better assignment of complex reactions and help in the design of new nitric oxide releasing complexes.

\section{EXPERIMENTAL}

\section{Chemicals and reagents}

Imidazole (99\%, Aldrich) was used without any further treatment. Ruthenium trichloride $\left(\mathrm{RuCl}_{3} \cdot \mathrm{nH}_{2} \mathrm{O}\right.$ ) (37 to $42 \% \mathrm{Ru}$, Aldrich) was used in the synthesis of $c i s-\left[\mathrm{RuCl}_{2}(\mathrm{bpy})_{2}\right]$. This latter complex was synthesized using a method previously described in literature..$^{50,51}$ Other reagents and solvents of analytical grade were used as purchased.

\section{Synthesis of the complex cis-[Ru( $\left.\left.\mathrm{NO}_{2}\right)(\mathrm{bpy})_{2}(\mathrm{imN})\right] P \mathrm{~F}_{6}(1)$}

This compound was prepared dissolving cis- $\left[\mathrm{RuCl}_{2}(\mathrm{bpy})_{2}\right](0.200 \mathrm{~g}$, $0.41 \mathrm{mmol})$ and imidazole $(\mathrm{ImN})(0.033 \mathrm{~g}, 0.49 \mathrm{mmol})$ in $20 \mathrm{ml}$ of a 
solution prepared by the ethanol-water mixture. The reactional system was kept under reflux for $2 \mathrm{~h}$. After this period, sodium nitrite $(0.035$ $\mathrm{g}, 0.49 \mathrm{mmol}$ ) was added to the solution and allowed to react under reflux for more $2 \mathrm{~h}$. The solid was obtained after addition of saturated ammonium hexafluorophosphate in aqueous solution $(1.0 \mathrm{~mL})$. Yield: 0.212 g, $76 \%$. $\mathrm{C}_{23} \mathrm{H}_{19} \mathrm{~F}_{6} \mathrm{~N}_{7} \mathrm{O}_{2} \mathrm{PRu}(672.36$ ): calcd. C $41.06 \%, \mathrm{H} 2.81 \%$, $\mathrm{N} 14.59 \%$; found $\mathrm{C} 41.22 \%, \mathrm{H} 2.78 \%, \mathrm{~N} 14.49 \%$. These data were obtained in a Perkin-Elmer CHN 2400 analyzer.

\section{Monitoring the nitrite/nitrosyl interconversion by High- Performance Liquid Chromatography}

The chromatographic analysis was performed on a Shimadzu liquid chromatograph equipped with a LC-10AD pump and SPDM10A UV-Visible photodiode-array detector with a CBM-10AD interface. An Alltech ODS reverse-phase column ( $250 \mathrm{~mm}$ x $4.6 \mathrm{~mm}$, $5 \mu \mathrm{m}$ particle) was used under isocratic elution regime with 15:85 acetonitrile-water solution containing $0.1 \%$ trifluoroacetic acid, $\mathrm{pH}$ $=3.5$. The chromatograms were obtained at a constant flow-rate of $1.0 \mathrm{~mL} \mathrm{~min}^{-1}$ after injecting $5 \mu \mathrm{L}$ of the solution, all monitoring was reported using a wavelength of $300 \mathrm{~nm}$.

The measurements were obtained using a $100 \mathrm{~mL}$ of cis$\left[\mathrm{Ru}\left(\mathrm{NO}_{2}\right)(\mathrm{bpy})_{2}(\mathrm{imN})\right]^{+}$aqueous solution at $5 \times 10^{-5}$ mol.L $\mathrm{L}^{-1}$ in $\mathrm{pH}$ $=8.0$ and temperature of $25^{\circ} \mathrm{C}$. Then $\mathrm{pH}$ was changed by addition of trifluoroacetic acid and maintaining the solution under constant agitation for five minutes before each injection.

After the nitrite complex was completely consumed as indicated by the area of the peak at 6.81 minutes, the volume of that solution was reduced to $10 \mathrm{~mL}$ and the complex $c i s-\left[\mathrm{Ru}(\mathrm{NO})(\mathrm{bpy})_{2}(\mathrm{imN})\right]^{3+}$ (2) was isolated and characterized by UV-Vis, Infrared, NMR spectroscopies and electrochemical techniques. The interconversion from $\mathrm{Ru}-\mathrm{NO}$ to $\mathrm{Ru}-\mathrm{NO}_{2}{ }^{-}$was also monitored by Uv-Vis spectroscopy as previously described. ${ }^{33}$

Electronic spectra were recorded in aqueous solution at room temperature on a UV-Vis, HP-8453 diode-array spectrophotometer. Vibrational spectra in the infrared region were obtained in potassium bromide pellets. The analysis was performed using an infrared spectrophotometer Shimadzu IR Prestige-21. The electrochemical measurements were performed in aqueous solution of NaTFA 0.1 mol L $\mathrm{L}^{-1}, \mathrm{pH}=3.4$, using the $\mathrm{Ag} / \mathrm{AgCl}$ (Epsilon potentiostat from Bioanalytical Systems) as reference electrode.

\section{Monitoring the reactions of nitrosyl complex with cysteine and methionine}

These chromatographic analysis were conducted mixing the complex 1 at $5.1 \times 10^{-5} \mathrm{~mol} \mathrm{~L}^{-1}$ with the sulfur-based reductants, cysteine or methionine at $5.1 \times 10^{-4} \mathrm{~mol} \mathrm{~L}^{-1}$, in an sodium acetate buffer $\mathrm{pH} 3.4$, ionic strength of $0.1 \mathrm{~mol} \mathrm{~L}^{-1}$.

A 15-fold ratio of cysteine or methionine over the concentration of the complex was kept to ensure a pseudo first-order condition. This reaction was monitored by HPLC with injections of $5 \mu \mathrm{L}$ of the mixture every 10 minutes, and temperature kept at $25^{\circ} \mathrm{C}$.

\section{RESULTS AND DISCUSSION}

\section{Monitoring the nitrite/nitrosyl interconversion}

The nitrosyl complex, cis-[Ru(NO)(bpy) $\left.{ }_{2}(\mathrm{imN})\right]^{3+}$ (compound 2), was obtained by acidification of the precursor cis- $\left[\mathrm{Ru}\left(\mathrm{NO}_{2}\right)\right.$ $\left.(\text { bpy })_{2}(\mathrm{imN})\right]^{+}$solution (compound 1$)$. This acid-base reaction is presented in Equation 2.

$c i s-\left[\mathrm{Ru}\left(\mathrm{NO}_{2}\right)(\mathrm{bpy})_{2}(\mathrm{imN})\right]^{+}{ }_{(\mathrm{aq})}+\mathrm{H}_{2} \mathrm{O}_{(\mathrm{l})} \underset{\mathrm{k}_{-1}}{\stackrel{\mathrm{k}_{1}}{\rightleftharpoons}}$ cis-[Ru(NO)(bpy)$\left.)_{2}(\mathrm{imN})\right]_{\left({ }_{(\mathrm{aq})}\right.}^{3+}+2 \mathrm{OH}_{(\mathrm{aq})}^{-}$

Electronic absorption study of this reaction showed one single inflection dependent of $\mathrm{pH}$ (Figure 1), indicating a equilibrium of interconversion described in Equation 2. As the $\mathrm{pH}$ of the solutions containing these complexes is increased, new intense bands with a maximum in the 400-450 $\mathrm{nm}$ range are observed. These bands can be assigned to the (bpy) $\pi^{*} \leftarrow \mathrm{d} \pi(\mathrm{Ru})$ MLCT transition of the nitro species formed according to the chemical equilibrium displayed. The determination of the both species present in equal concentrations for Equation 2 was carried out using the spectrophotometric method (absorbance measurements were performed at $410 \mathrm{~nm}$ ). The total ionic strength was kept at $0.5 \mathrm{~mol} \mathrm{~L}^{-1}$ with sodium trifluoroacetate, according to similar studies reported for the $\mathrm{Ru}^{\mathrm{II}}{ }^{33}$ systems. The $\mathrm{pKa}$ for this process was determined as 5.54, which is close to the value measured for other similar nitrosyl complexes having bipyridine and auxiliary nitrogen-bound ligands. ${ }^{33}$

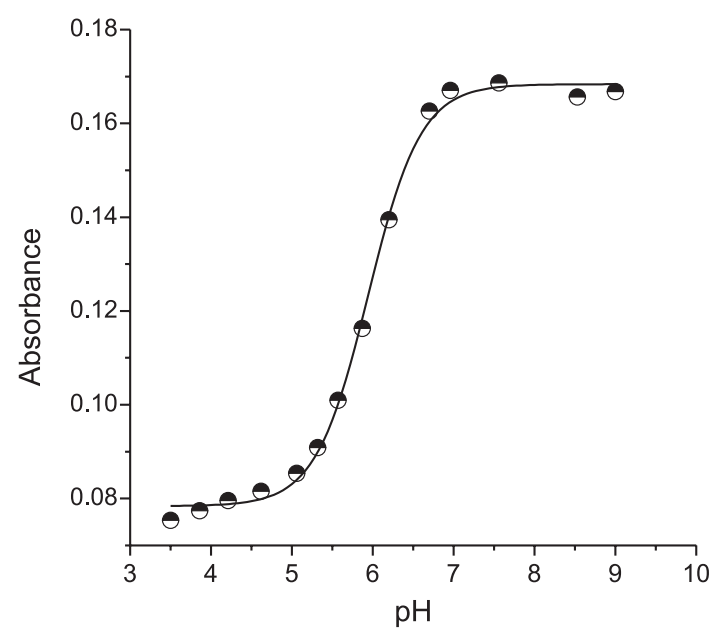

Figure 1. Spectrophotometric monitoring of the interconversion of cis$-\left[\mathrm{Ru}(\mathrm{NO})(\text { bpy })_{2}(\mathrm{imN})\right]^{3+}$ into cis- $\left[\mathrm{Ru}\left(\mathrm{NO}_{2}\right)(\text { bpy })_{2}(\mathrm{imN})\right]^{+}$at different $\mathrm{pH}$ values $\left(\lambda_{\max }=410 \mathrm{~nm}\right.$; NaTFA aqueous solution, $\left.\mu=1.0 \mathrm{~mol} . \mathrm{L}^{-1}\right)$

The chromatogram of 1 at $\mathrm{pH} 8.0$ showed only one peak with retention time of 6.81 minutes (Figure 2). The absence of any additional peak indicated the stability of the nitrite ion coordinated to the $\mathrm{Ru}(\mathrm{II})$ metal in that $\mathrm{pH}$. However, upon a gradual decrease of the $\mathrm{pH}$ of the solution until $\mathrm{pH} 3.5$, the chromatographic profile changed dramatically (Figure 2). Already at pH 6.5, the area of the peak corresponding to compound 1 decreased and additional peaks with lower retention time were observed.

Of course, the rate of this reaction is extremely $\mathrm{pH}$ dependent, and at very low $\mathrm{pH}(\mathrm{pH}<3.0), \mathrm{k}_{1}$ is very high. For the reverse reaction $\left(\mathrm{k}_{-1}\right)$ where there is a hydroxide attack, this reaction rate follows the opposite trend, i.e. higher rate constant at high $\mathrm{pH}$ values. ${ }^{27,52,53}$ The detection of the chemical specie formed in nitrite complex solution when it is submitted to different $\mathrm{pH}$ conditions was monitored by HPLC (Figure 2).

Figure 2a showed the chromatogram of cis-[Ru(NO $\left.\mathrm{NO}_{2}\right)$ (bpy) $\left.{ }_{2}(\mathrm{imN})\right]^{+}\left(\right.$compound $\left.1, \mathrm{t}_{\mathrm{R}}=3.92 \mathrm{~min}\right)$ and $\operatorname{cis}$ - $[\mathrm{Ru}(\mathrm{NO})$ (bpy) $\left.{ }_{2}(\mathrm{imN})\right]^{3+}$ (compound 2, $\mathrm{t}_{\mathrm{R}}=6.81 \mathrm{~min}$ ) complexes ions, with their respective UV-Vis spectra. There are strong differences in their electronic spectra and retention times, supporting the appropriated use of HPLC. This is a reasonable behavior since the charge of the nitrosyl complex was higher than the nitrite complex. Thus, it is rational to expect the nitrosyl complex exhibited a more polar character than the nitrite one. So, the former would be less retained on the column, consequently, showing a shorter retention time. Interestingly, in addition to the main peaks corresponding to nitro and nitrite complexes, other peaks with low intensity were observed, which had been assigned to possible intermediates formed during the 

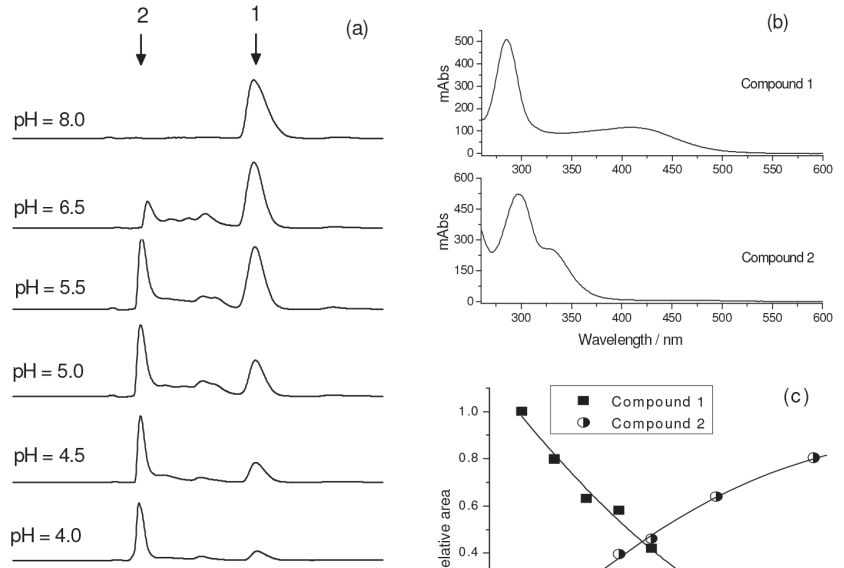

$\mathrm{pH}=4.0$
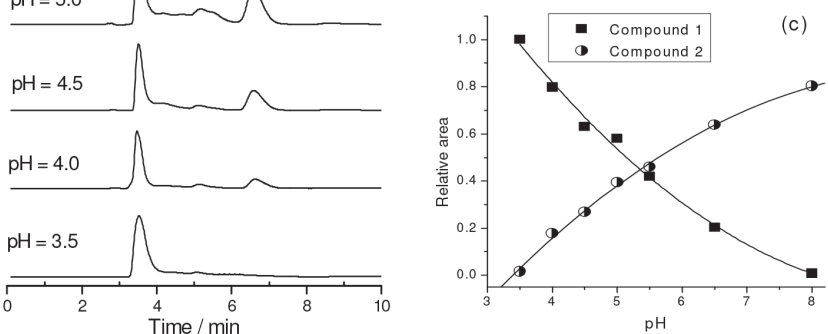

Figure 2. HPLC monitoring of the interconversion reaction of nitrite/nitrosyl, at $300 \mathrm{~nm}$. Figure 2 a showed the chromatogram of cis-[Ru(NO$\left.\left.{ }_{2}\right)(\text { bpy })_{2}(\mathrm{imN})\right]^{+}$ (compound $\left.1, t_{R}=3.92 \mathrm{~min}\right)$ and cis- $\left[\mathrm{Ru}(\mathrm{NO})(\mathrm{bpy})_{2}(\mathrm{imN})\right]^{3+}\left(\right.$ compound $2, t_{R}$ $=6.81 \mathrm{~min}$ ) complexes ions, with their respective $U V$-Vis spectra. (b) UV-Vis spectrum of the cis- $\left[\mathrm{Ru}\left(\mathrm{NO}_{2}\right)(\mathrm{bpy})_{2}(\mathrm{imN})\right]^{+}(1)$ and cis- $\left[\mathrm{Ru}(\mathrm{NO})(\mathrm{bpy})_{2}(\mathrm{imN})\right]^{3+}$ (2) as obtained from HPLC. (c) Profile for the reaction of 1 with $\mathrm{H}^{+}$as monitored by HPLC: black squares (relative area for peak of 3.92 minutes) and black circles (relative area for peak of 6.81 minutes)

interconversion process. This behavior was reported by other kinetic studies indicating multiple steps. . $1-24,31-33,35^{-10}$

There is an efficient consumption of $c i s-\left[\mathrm{Ru}\left(\mathrm{NO}_{2}\right)(\mathrm{bpy})_{2}(\mathrm{imN})\right]^{+}$ with concomitant production of $c i s-\left[\mathrm{Ru}(\mathrm{NO})(\mathrm{bpy})_{2}(\mathrm{imN})\right]^{3+}$ species, as indicated in the chromatogram along with the identification of these species by their UV-vis spectra (Figure 2b). After addition of $\mathrm{H}_{3} \mathrm{O}^{+}$, the major peak was at 3.92 min corresponding to compound 2 as shown by the chromatograms (Figure 2a).

The electrophilic reactions of the NO ligand bound to transition metal centers have long been study and constitute one of the important reactivity properties for these compounds. ${ }^{29,34}$ It has been reported that when solutions of $\{\mathrm{MNO}\}^{6}$ complexes are made alkaline, ${ }^{36,40} \mathrm{a}$ product with absorption band from $300-400 \mathrm{~nm}$ is observed..$^{31,52,53}$ Additionally, this transformation is fully reversible upon addition of acid. Currently, there is no debate regarding the nature of this reaction corresponding to the interconversion of the nitrosyl complex into the nitrite. ${ }^{31,52,53}$ This resulted by a nucleophilic attack of the hydroxyl into the $\mathrm{NO}^{+}$group, and a new band observed in $400 \mathrm{~nm}$ may be assigned to a metal to ligand charge transfer from $\mathrm{Ru}(\mathrm{II})$ to the $\mathrm{NO}_{2}{ }^{-}$ligand. ${ }^{31,52}$

Based on kinetics studies, ${ }^{31,52-54}$ a series of step reactions have been proposed to explain the pathways of the nitrite/nitrosyl interconversion as described below.

$$
\begin{aligned}
& c i s-\left[\mathrm{Ru}\left(\mathrm{NO}_{2}\right)(\mathrm{bpy})_{2}(\mathrm{imN})\right]^{+}{ }_{(\mathrm{aq})}+\mathrm{H}_{2} \mathrm{O}_{(\mathrm{l})} \stackrel{\mathrm{k}_{2}}{\rightleftharpoons} c i s-\left[\mathrm{Ru}\left(\mathrm{NO}_{2} \mathrm{H}\right)(\mathrm{bpy})_{2}(\mathrm{imN})\right]^{2+}{ }_{(\mathrm{aq})}+\mathrm{OH}_{(\mathrm{aq})}^{-}(3) \\
& c i s-\left[\mathrm{Ru}\left(\mathrm{NO}_{2} \mathrm{H}\right)(\mathrm{bpy})_{2}(\mathrm{imN})\right]^{2+}{ }_{(\mathrm{aq})} \stackrel{\mathrm{k}_{3}}{\longrightarrow} c i s-\left\{\left[\mathrm{Ru}(\mathrm{NO})(\mathrm{bpy})_{2}(\mathrm{imN})\right] \cdot \mathrm{OH}^{-}\right\}^{2+}{ }_{(\mathrm{aq})} \\
& c i s-\left\{\left[\mathrm{Ru}(\mathrm{NO})(\mathrm{bpy})_{2}(\mathrm{imN})\right] \cdot \mathrm{OH}^{-}\right\}^{2+}{ }_{(\mathrm{aq})} \stackrel{\mathrm{k}_{4}}{\longrightarrow} c i s-\left[\mathrm{Ru}(\mathrm{NO})(\mathrm{bpy})_{2}(\mathrm{imN})\right]^{3+}{ }_{(\mathrm{aq})}+\mathrm{OH}_{(\mathrm{aq})}^{-}
\end{aligned}
$$

Thus, it is reasonable to conclude that the extra small peaks observed during the chromatograms could be due to actual intermediates as proposed in the above mechanism.

Figure $2 \mathrm{c}$ shows the equilibrium plot as a function of $\mathrm{pH}$ for the reaction of nitrite/nitrosyl interconversion. The graph shows significant correlation between a decrease in peak attributed to the compound 1 and the appearance of the peak referring of the compound 2 as a result of the addition of $\mathrm{H}_{3} \mathrm{O}^{+}$. This profile is due to an equilibrium of these species $\left(\mathrm{NO}^{+} / \mathrm{NO}_{2}{ }^{-}\right)$. The use of HPLC proved to be a great support for monitoring this reaction and identifying species involved in the reaction of nitrite/nitrosyl interconversion. Additionally, it indicated also a great similarity in the pKa value calculate by UV-visible spectroscopy $(\mathrm{pKa}=5.54),{ }^{33}$ reinforcing the possibility to determine this parameter using HPLC.

Aiming to assure the nature of the final product after reaching the lowest $\mathrm{pH}$, this compound was isolated by addition of a saturated solution of $\mathrm{NH}_{4} \mathrm{PF}_{6}$ and characterized by UV-Vis, FTIR and electrochemical techniques. This product showed all features found for $c i s-\left[\mathrm{Ru}(\mathrm{NO})(\mathrm{bpy})_{2}(\mathrm{imN})\right]^{3+}$ complex, such as electronic spectrum in water showing an intense band at $290 \mathrm{~nm}\left(2.45 \times 10^{4} \mathrm{~L} \mathrm{~mol}^{-1} \mathrm{~cm}^{-1}\right)$ attributed to the ligand $\pi^{*} \leftarrow \pi$ (bpy) transition. ${ }^{55,56}$ Also, another absorption band at $323 \mathrm{~nm}\left(8.92 \times 10^{3} \mathrm{~L} \mathrm{~mol}^{-1} \mathrm{~cm}^{-1}\right)$ was observed attributed to MLCT, (bpy) $\pi^{*} \leftarrow \mathrm{d} \pi(\mathrm{Ru})$. For this type of complex, one absorption is also expected due to $\left(\mathrm{NO}^{+}\right) \pi^{*} \leftarrow \mathrm{d} \pi(\mathrm{Ru})$. Armor and Pell ${ }^{57}$ observed this transition for complexes of the type cis$\left[\mathrm{Ru}(\mathrm{NO})\left(\mathrm{NH}_{3}\right)_{4} \mathrm{X}\right]^{+\mathrm{n}}$, where $\mathrm{X}=\mathrm{OH}^{-}, \mathrm{Cl}^{-}, \mathrm{Br}^{-}$, or $\mathrm{I}^{-}$and $\mathrm{n}=2$; or $\mathrm{X}=$ $\mathrm{H}_{2} \mathrm{O}$ and $\mathrm{n}=3$ ) with $\varepsilon \sim 50 \mathrm{~L}$. $\mathrm{mol}^{-1} \mathrm{~cm}^{-1}$. For ruthenium bipyridine complexes, this band is observed with a higher energy than in the case of tetraamines due to the stabilization of the $d \pi(R u)$ orbitals caused by the ligands. Thus, in the $c i s-\left[\mathrm{Ru}(\mathrm{NO})(\mathrm{bpy})_{2}(\mathrm{imN})\right]\left(\mathrm{PF}_{6}\right)_{3}$ this band is probably overlapped by the intense band at $323 \mathrm{~nm}$.

Additionally, it was found a very intense peaks in the FTIR spectrum at $1944 \mathrm{~cm}^{-1}$ assigned to the $\mathrm{vNO}^{+}$vibrational mode characteristic of similar systems. ${ }^{10,30,58-61}$ The $c i s-\left[\mathrm{Ru}(\mathrm{NO})(\mathrm{bpy})_{2}(\mathrm{imN})\right]$ $\left(\mathrm{PF}_{6}\right)_{3}$ complex cyclic voltammetry obtained in $0.1 \mathrm{~mol} \mathrm{~L}^{-1}$ reveals only reversible electrochemical process characteristic of the nitrosyl ligand, also noticed for the isolated compound.

\section{Monitoring the reaction of the nitrosyl complex with cysteine and methionine}

The nucleophilic reactions promoted by thiols have been studied for a series of ruthenium nitrosyl complexes..$^{34,62}$ The rate of this reaction is also extremely dependent of the concentration of $\mathrm{H}_{3} \mathrm{O}^{+}$, whereas at higher $\mathrm{pH}$ the reaction occurs faster. Due to this, we decided to work at $\mathrm{pH} 3.5$, since it would slow down the reaction and make possible to follow the products by HPLC. Additionally, at this $\mathrm{pH}$ we can assure the complex is in a nitrosyl form.

The chromatogram corresponding to the reaction of the cis$\left[\mathrm{Ru}(\mathrm{NO})(\mathrm{bpy})_{2}(\mathrm{imN})\right]^{3+}$ complex with cysteine can be observed in Figure 3a. In the first chromatogram, before cysteine addition, there was only one major peak at 2.72 minutes retention time whose electronic spectra was also consistent with compound 2. Interestingly, right after the addition of cysteine, it was observed formation of a new species (compound 3) with peak at 3.38 minutes. The electronic spectrum of this compound 3 (Figure $3 \mathrm{~b}$ ) showed band at $380 \mathrm{~nm}$, which is consistent with the same intermediate $\mathrm{I}_{2}\left(\right.$ cis- $\left[\mathrm{Ru}\left(\mathrm{N}(\mathrm{O})(\mathrm{SR})_{2}\right)\right.$ $\left.(\text { bpy })_{2}(\mathrm{imN})\right]^{+}$) described by stopped-flow studies by Silva et al. ${ }^{63}$

Later on, another chromatographic peak at 4.15 minutes was observed, assigned to compound 4. This latter showed a metalto-ligand charge transfer (MLCT) transition band, $\mathrm{d} \pi(\mathrm{Ru}) \leftarrow \pi^{*}$ (bipyridine), with maximum at $470 \mathrm{~nm}$, which indicated formation of the $c i s$ - $\left[\mathrm{Ru}(\mathrm{bpy})_{2}(\mathrm{imN})\left(\mathrm{H}_{2} \mathrm{O}\right)\right]^{2+}$ complex (Figure $\left.3 \mathrm{~b}\right) .^{33}$ The intense electronic transition bands observed upon addition of cysteine to sodium nitroprusside (NP ${ }^{62}$ and also to the complex investigated here can be described as due to MLCT of the $\left\{(\mathrm{X})_{5} \mathrm{MN}(\mathrm{O}) \mathrm{SR}\right\}$ adducts. These results corroborated with the proposed kinetic mechanism. ${ }^{63}$

Based on kinetic studies, ${ }^{23,35,63}$ the first step of this reaction is the formation of the intermediate $I_{1}$ which occured very fast and we were not able to measure the rate constant. ${ }^{62}$ Therefore, our study was 
unable to monitor $\mathrm{I}_{1}\left(\right.$ cis- $\left.\left[\mathrm{Ru}(\mathrm{N}(\mathrm{O})(\mathrm{SR}))(\mathrm{bpy})_{2}(\mathrm{imN})\right]^{2+}\right)$ formation.

Figure $3 \mathrm{c}$ shows the relative kinetic profile of the areas of the peaks of each species generated during this reaction. This result indicates a similar behavior as described by the kinetic study ever conducted for similar systems, ${ }^{62,63}$ where there is formed an $\mathrm{I}_{2}$ intermediate (compound 3) with the peak chromatogram being formed during $30 \mathrm{~min}$ and then there is a subsequent decay to the final product (compound 4) and $\mathrm{NO}^{0}$ release. The analysis monitored by HPLC there is a separation of the substances formed during the reaction enabling the identification of each species.

Roncaroli and Olabe ${ }^{62}$ proposed the following mechanism for the reaction of complex nitrosyl with cysteine:

$$
\left.\left[(\mathrm{X})_{5} \mathrm{RuNO}^{\mathrm{n}} \underset{-\mathrm{RS}^{-}}{\stackrel{\mathrm{RS}^{-}}{\perp}}\left[(\mathrm{X})_{5} \mathrm{RuN}(\mathrm{O}) \mathrm{SR}\right)\right]^{\mathrm{n}-1} \underset{-\mathrm{RS}^{-}}{\stackrel{\mathrm{RS}^{-}}{\rightleftharpoons}}\left[(\mathrm{X})_{5} \mathrm{RuN}(\mathrm{O})(\mathrm{SR})_{2}\right)\right]^{\mathrm{n}-2}
$$$$
\left[(\mathrm{X})_{5} \mathrm{Ru}\left(\mathrm{H}_{2} \mathrm{O}\right)\right]^{\mathrm{n}-1}+{ }^{1} / 2 \mathrm{~N}_{2} \mathrm{O}+\mathrm{RSSR}
$$

In a similar way, the reaction with the complex studied here can be described as occurring in three steps (Scheme 1) according:

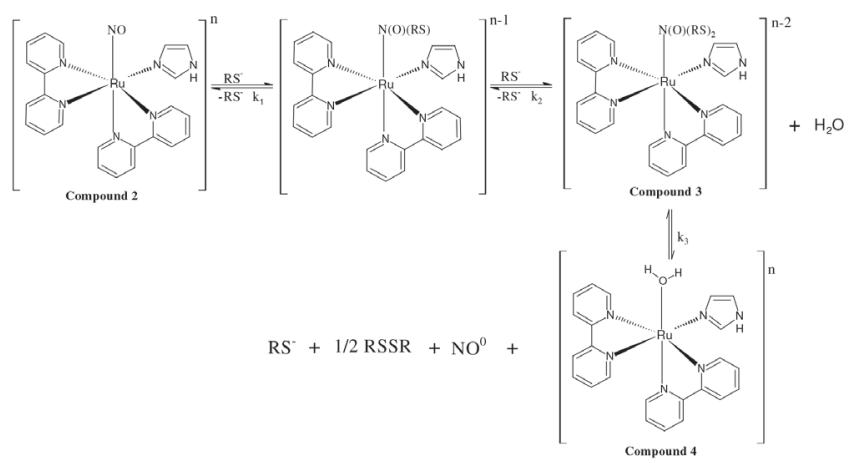

Scheme 1. Reaction scheme of cis-[Ru(NO)(bpy) $\left.)_{2}(\mathrm{imN})\right]^{3+}$ complex with cysteine monitored by HPLC

Aiming to investigate the role of this deprotonation in the reaction with nitrosyl complex, we decided to use methionine and monitored the reaction by HPLC. The chromatograms showed an initial peak at 2.31 minutes corresponding to the nitrosyl complex (cis-[Ru(NO) $\left.(\text { bpy })_{2}(\mathrm{imN})\right]\left(\mathrm{PF}_{6}\right)_{3}$, compound 2) that decreased over time while another peak at 3.67 minutes was formed. This latter peak was assigned to the ruthenium aqua complex (Scheme 1, compound 4), which may be formed due to the release of nitric oxide.

Interestingly, in these experiments, it was not observed the formation of any intermediate, as observed for the reaction with cysteine (Figure 4b). Once methionine presented a methyl group in place of hydrogen, the redox process happens without formation of the adducts $\left(I_{1}\right.$ and compound 3$)$. This result corroborated with kinetic data by stopped-flow, ${ }^{63}$ which indicated formation of intermediates only using thiols and the nitric oxide accelerates the reaction rate.

\section{CONCLUSIONS}

Our results showed that HPLC can be used as a powerful technique to monitor and characterize more complex reactions involving metal complexes such as nitrite/nitrosyl interconversion in ruthenium bipyridine complexes. It was possible to follow and assigned products observed during the reaction of $c i s-[\mathrm{Ru}(\mathrm{NO})$ $\left.(\mathrm{bpy})_{2}(\mathrm{imN})\right]\left(\mathrm{PF}_{6}\right)_{3}$, with cysteine and methionine, and supported by other techniques to better describe a mechanism for these reactions. Nevertheless, HPLC was suitable to identify and monitor the
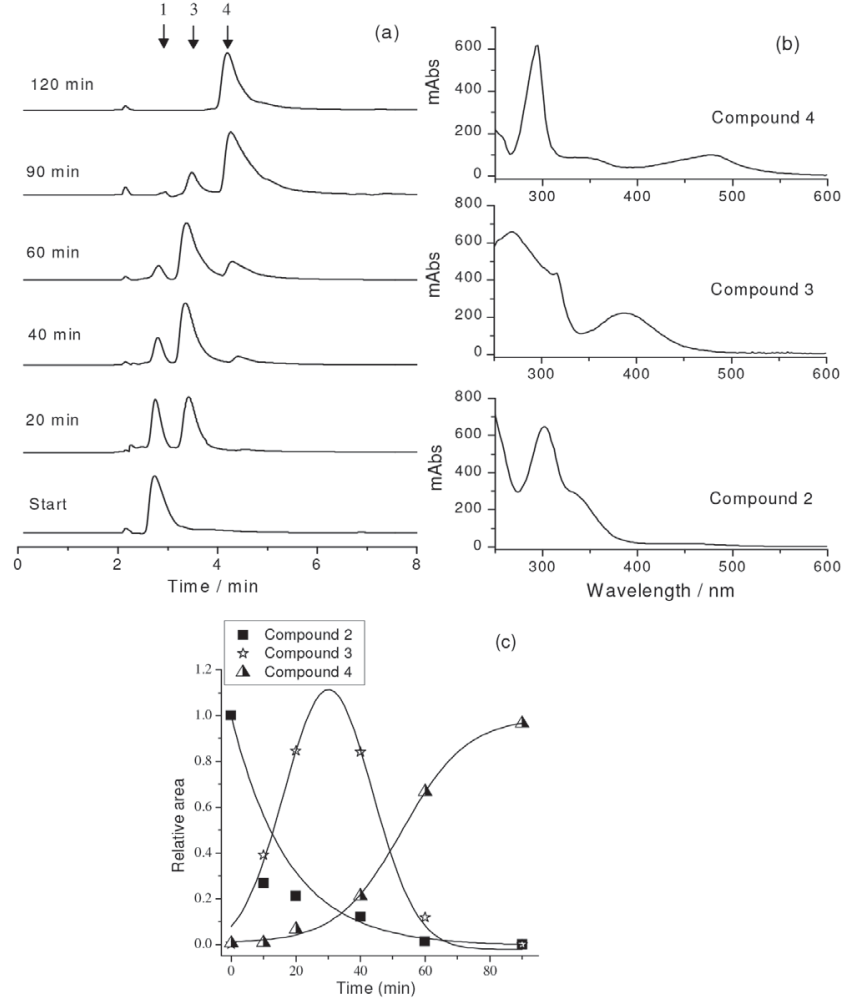

Figure 3. Monitoring the reaction of cis-[Ru(NO) $\left.(\text { bpy })_{2}(\mathrm{imN})\right]^{3+}$ with cysteine using HPLC. (a) Chromatograms for the reaction carried out in $0.1 \mathrm{~mol}$. $\mathrm{L}^{-1}$ acetate buffer $p H$ 3.5. (b) UV-Vis spectra of cis-[Ru(NO)(bpy) $\left.)_{2}(\mathrm{imN})\right]^{3+}(2)$, peak at retention time $2.72 \mathrm{~min}$, cis- $\left[\mathrm{Ru}(\mathrm{N}(\mathrm{O}) \mathrm{RS})_{2}(\mathrm{bpy})_{2}(\mathrm{imN})\right]^{+}$(3) at 3.38 min and cis-[Ru(bpy $\left.)_{2}(\mathrm{imN})\left(\mathrm{H}_{2} \mathrm{O}\right)\right]^{2+}(4)$ at $4.15 \mathrm{~min}$. (c) Kinetic profile using peak area for each species, black squares (at $2.72 \mathrm{~min}$ ), stars (at $3.38 \mathrm{~min}$ ) and black triangles (at $4.15 \mathrm{~min}$ )
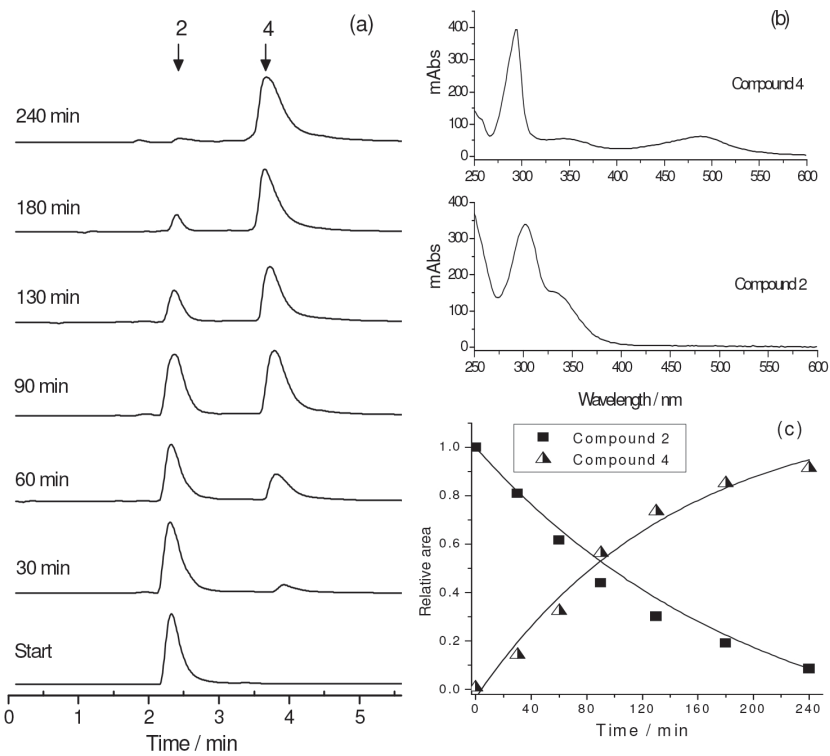

Figure 4. Monitoring the reaction of cis-[Ru(NO)(bpy)$(\mathrm{imN})]^{3+}$ with methionine using HPLC. (a) Chromatograms for the reaction carried out in $0.1 \mathrm{~mol}$. $L^{-1}$ acetate buffer pH 3.5. (b) UV-Vis spectra of the peaks at retention times 2.31 min, cis- $\left[\mathrm{Ru}(\mathrm{NO})(\mathrm{bpy})_{2}(\mathrm{imN})\right]^{3+}(2)$ and $3.67 \mathrm{~min}, \mathrm{cis}-\left[\mathrm{Ru}(\mathrm{bpy})_{2}(\mathrm{imN})\left(\mathrm{H}_{2} \mathrm{O}\right)\right]^{+}$ (4). (c) Kinetic profile for the reaction of cis-[Ru(NO)(bpy) $\left.2_{2}(\mathrm{imN})\right]^{3+}$ complex ion with methionine monitored by HPLC: black squares (relative area for peak of 2.31 minutes) and black triangle (relative area for peak of 3.67 minutes) 
formation and consumption of intermediate species of the reaction of thiols with nitrosyl complexes.

\section{ACKNOWLEDGEMENTS}

The authors acknowledge the Brazilian agencies CNPq, CAPES, and FUNCAP for the financial support: L. G. F. Lopes $(\mathrm{CNPq}$ 303732/2014-8; PPSUS 12535691-9), E. H. S. Sousa (PVE - 09/ 2014 process 88881.068193/2014-01, CNPq 312030/2015-0) and F. O. N. Silva (CNPq: 4425868/2014-2) are supported by the National Council for Scientific and Technological Development of Brazil.

\section{REFERENCES}

1. Moncada, S.; Palmer R. M.; Higgs, E. A.; Pharmacol. Rev. 1991, 43, 109.

2. Feldman, P. L.; Griffith, O. W.; Stuchr, D.; J. Chem. Eng. News. 1993, $71,26$.

3. Mccleverty, J. A.; Chem. Rev. 2004, 104, 403.

4. Mel, A.; Murad, F; Seifalian, A. M.; Chem. Rev. 2011, 111, 5742.

5. Caramori, G. F.; Ortolan, A. O.; Parreira, R. L. T.; Silva, E. H.; J. Organomet. Chem. 2015, 799-800, 54.

6. El-Sehemy, A; Postovit, L. M; Fu, Y.; Nitric Oxide 2016, 54, 30.

7. Tfouni, E.; Ferreira, K. Q.; Doro, F. G.; Silva, R. S.; Rocha, Z. N.; Coord. Chem. Rev. 2005, 249, 405.

8. Tfouni, E; Truzzi, D. A.; Tavares, A.; Gomes, A. J.; Figueiredo, L. E.; Franco, D. W.; Nitric Oxide 2012, 26, 38.

9. Kamatchi, T. S.; Chitrapriya, N.; Ahamed, V. S. J.; Moon, S.; Fronczek, F. R.; Natarajan, K.; Inorg. Chim. Acta. 2013, 404, 58.

10. Rodrigues, F. P.; Carneiro, Z. A.; Mascharak, P.; Curti, C.; Silva, R. S.; Coord. Chem. Rev. 2016, 306, 701.

11. Balzani, V.; Juris, A.; Coord. Chem. Rev. 2001, 211, 97.

12. Furue, M.; Ishibashi, M.; Satoh, A.; Oguni, T.; Maruyama, K.; Sumi, K., Kamachi, M.; Coord. Chem. Rev. 2000, 208, 103.

13. Tyson, D. S.; Luman, C. R.; Zhou, X. L.; Castellano, F. N.; Inorg. Chem. 2001, 40, 4063.

14. Walters, K. A.; Trouillet, L.; Guillerez, S.; Schanze, K. S.; Inorg. Chem. 2000, 39, 5496.

15. Hu, Y. Z.; Tsukiji, S.; Shinkai, S.; Oishi, S.; Hamachi, I. J.; Am. Chem. Soc. 2000, 122, 241.

16. Luo, J.; Reddy, K. B.; Salameh, A. S.; Wishart, J. F.; Isied, S. S.; Inorg. Chem. 2000, 39, 2321.

17. Stemp, E. D. A.; Holmlin, R. E.; Barton, J. K.; Inorg. Chim. Acta. 2000 , 297, 88.

18. Furue, M.; Maruyama, K.; Kanematsu, Y.; Kushida, T.; Kamachi, M.; Coord. Chem. Rev. 1994, 132, 201.

19. Grabulosa, A.; Beley, M.; Gros, P. C.; Eur. J. Inorg. Chem. 2008, 11, 1747.

20. Pearson, P.; Bond, A. M.; Deacon, G. B.; Forsyth, C.; Spiccia, L.; Inorg. Chim. Acta. 2008, 361, 601.

21. Moreira, I. S.; Santiago, M. O.; Chromatographia 1996, 43, 322.

22. Meyer, T. J.; Wals, J. L.; Bullock, R. M.; Inorg. Chem. 1980, 19, 865.

23. Diogenes, I. C. N.; Sousa, J. R. d., Moreira, I. S.; Chromatographia 2000, 51, 122.

24. Sauaia, M. G.; Tfouni, E.; Santos, R. H. A.; Gambardella, M. T. P.; Lama, M. P. F. M. D.; Guimarães, L. F.; Silva, R. S. D.; Inorg. Chem. Commun. 2003, 6, 864.

25. Oliveira, F. M.; Santana, D. C. A.; Taveira, S. F.; Vermeulen, D. M.; Oliveira, A. R. M.; Silva, R. S.; Lopez, R. F. V.; J. Pharm. Biomed. Anal. 2010, 53, 843 .

26. Durham, B.; Wilson, S. R.; Hodgson, D. J.; Meyer, T. J.; J. Am. Chem. Soc. 1980, 102, 600 .

27. Togano, T.; Kuroda, H.; Nagao, N.; Maekawa, Y.; Nishimura, H.; Howell, F. S.; Mukaida, M.; Inorg. Chim. Acta, 1992, 196, 57.
28. Nagao, H.; Nishimura, H.; Funato, H.; Ichikawa, Y.; Howell, F. S.; Mukaida, M.; Kakihana, H.; Inorg. Chem. 1989, 28, 3955.

29. Richter-Addo, G. B.; Legzdins, P. Metal Nitrosyls. Oxford University Press: New York, 1992.

30. Gomes, M. G.; Davanzo, C. U.; Silva, S. C.; Lopes, L. G. F.; Santos, P. S., Franco, D. W. J.; Chem. Soc. Dalton Trans. 1998, 601.

31. Roncaroli, F.; Ruggiero, M. E.; Franco, D. W.; Estiu, G., Olabe, J. A.; Inorg. Chem. 2002, 41, 5760.

32. Toledo, J. C.; Silva, H. A. S.; Scarpellini, M.; Mori, V.; Camargo, A. J.; Bertotti, M., Franco, D. W.; Eur. J. Inorg. Chem. 2004, 1879.

33. Silva, F. O. N.; Araújo, S. X. B.; Holanda, A. K. M.; Meyer, E.; Sales, F. A. M.; Diógenes, I. C. N.; Carvalho, I. M. M.; Moreira, I. S.; Lopes, L. G. F.; Eur. J. Inorg. Chem. 2006, 2020.

34. Souza, M. L.; Roveda Jr, A. C.; Pereira, J. C. M.; Franco, D. W.; Coord. Chem. Rev. 2016, 306, 615.

35. Godwin, J. B., Meyer, T. J.; Inorg. Chem. 1971, 10, 471.

36. Bottomley, F.; Reactions of Coordinated Ligands, vol 2, Ed. Braterman, P. S. Plenum: New York, 1989, p. 115.

37. Ford, P. C.; Lorkovic, I. M.; Chem. Rev. 2002, 102, 993.

38. Ford, P. C.; Laverman, L. E.; Lorkovic, I. M.; Adv. Inorg. Chem. 2003, $54,203$.

39. Olabe, J. A.; Adv. Inorg. Chem. 2004, 55, 61.

40. Roncaroli, F.; Videla, M.; Slep, L. D.; Olabe, J. A.; Coord. Chem. Rev. 2007, 251, 1903.

41. Johnson, M.; Wilkins, R. G.; Inorg. Chem. 1984, 23, 231.

42. Szacilowski, K.; Stochel, G.; Stasicka, Z.; Kisch, H.; New J. Chem. 1997, 21, 893.

43. Sevcíková, R.; Lubal, P.; Campello, M. P. C.; Santos, I. Polyhedron 2013, 62, 268.

44. Morando, P. J.; Borghi, E. B.; Schteingart, L. M.; Blesa, M. A. J.; Chem. Soc. Dalton Trans. 1981, 435.

45. Butler, A.R.; Calsy-Harrison, A.M.; Glidewell, C.; Polyhedron 1988, 7, 1197.

46. Szacilowski, K.; Wanat, A.; Barbieri, A.; Wasielewska, E.; Witko, M.; Stochel, G.; Stasicka, Z.; New J. Chem. 2002, 26, 1495.

47. Smith, J. N.; Dasgupta, T. P.; Inorg. React. Mech. 2002, 3, 181.

48. Grossi, L.; D’Angelo, S.; J. Med. Chem. 2005, 48, 2622.

49. Vanin, A. F.; Nitric Oxide 2016, 54, 15.

50. Sullivan, B. P.; Salmon, D. J.; Meyer, T. J.; Inorg. Chem. 1978, 17, 3334.

51. Norris, M. R.; Concepcion, J. J.; Glasson, C. R. K.; Fang, Z.; Lapides, A. M.; Ashford, D. L.; Templeton, J. L.; Meyer, T. J.; Inorg. Chem. 2013, 52, 12492.

52. Chevalier, A. A.; Gentil, L. A., Olabe, J. A.; J. Chem. Soc. Dalton Trans. 1991, 1959.

53. Videla, M.; Jacinto, J. S.; Baggio, R.; Garland, M. T.; Singh, P.; Kaim, W.; Slep, L. D.; Olabe, J. A.; Inorg. Chem. 2006, 45, 21.

54. Levin, N.; Codesido, N. O.; Bill, E.; Weyhermüller, T.; Gaspari, A. P. S.; Silva, R. S.; Olabe, J. A.; Slep, L. D.; Inorg. Chem. 2016, 55, 7808.

55. Callahan, R. W.; Meyer, T. J.; Inorg. Chem. 1977, 16, 574.

56. Boonyavonga, N.; Suwanruji, P.; Hannongbua, S.; Li, F.; Sunc, L.; Karpkirda, T. M.; J. Photochem. Photobiol., A. 2014, 287, 40.

57. Pell, S.; Armor, J. N.; Inorg. Chem. 1973, 12, 873.

58. Borges, S. S. S.; Davanzo, C. U.; Castellano, E. E.; Schpector, Z.; Silva, S. C.; Franco, D. W.; Inorg. Chem. 1998, 37, 2670.

59. Lopes, L. G. F.; Wieraszko, A.; El-Sherif, Y.; Clarke, M. J.; Inorg. Chim. Acta. 2001, 312, 15.

60. Wieraszko, A.; Clarke, M. J.; Lang, D. R.; Lopes, L. G. F.; Franco, D. W.; Life Sci. 2001, 68, 1535.

61. Poelhsitz, G. V.; Bogado, A. L.; Souza, G. D.; Rodrigues-Filho, E.; Batista, A. A.; Araujo, M. P.; Inorg. Chem. Commun. 2007, 10, 133.

62. Roncaroli, F.; Olabe, J.A.; Inorg. Chem. 2005, 44, 4719.

63. Silva, F. O. N.; Cândido, M. C. L.; Holanda, A. K. M.; Diógenes, I. C. N.; Sousa, E. H. S.; Lopes, L. G. F.; J. Inorg. Biochem. 2011, 105, 624. 